11. Буссе Ральф. Обзор антикризисных налоговых мер в Европе // Антикризисные или конъюнктурные пакеты : материалы II Международного научно-практического симпозиума по актуальным проблемам налоговой политики // Вестник палаты налоговых консультантов. - 2009. - № 5-6 // [Электронный ресурс]. - Режим доступа : http://www.palata-

nk.ru/php/content.php?id=1726.
12. Досвід країн світу щодо подолання наслідків світової фінансової кризи [Електронний ресурс]. - Режим доступу: // http://www.me.gov.ua/file/link/

146035/file/krisis_p.doc

13. Економічна криза в Україні: виміри, ризики, перспективи [Електронний ресурс] - Режим доступу до ресурсу: http://www.niss.gov.ua/book/vidannya/Ekon.kriz a.pdf.

Рецензент д.е.н., професор УкрДУЗТ Зайцева І.Ю. Експерт редакційної колегії к.е.н., доцент УкрДУЗТ Токмакова І.В.

УДК 339.727

\title{
АНАЛІЗ СУЧАСНИХ ТЕНДЕНЦІЙ РОЗВИТКУ МІЖНАРОДНОГО ФОНДОВОГО РИНКУ
}

\author{
Савін Р.С., аспірант (ХНУ ім. В.Н.Каразіна)
}

\begin{abstract}
В роботі проаналізовані тендениії сучасного етапу розвитку міжнародного фондового ринк в інформаційній економіці. Суттєве місие відводиться позииіюванню міжнародного фондового ринку в глобальній фінансовій архітектурі та тій ролі, яку відіграють транскордонні потоки капіталів в формуванні його ключової тенденції. Показані процеси трансформаиії інституціональної структури міжнародного фондового ринку та роль та значимість міжнародних фінансових центрів в процесі глобалізащії. Визначені подальші шляхи розвитку фондового ринку Украӥни для інтеграції у світове господарство
\end{abstract}

Ключові слова : глобалізація, міжнародний фондовий ринок, міжснародні фінансові центри, інтернаціоналізація, інформаційні технології, цінні папери.

\section{АНАЛИЗ СОВРЕМЕННЫХ ТЕНДЕНЦИЙ РАЗВИТИЯ МЕЖДУНАРОДНОГО ФОНДОВОГО РЫНКА}

\author{
Савин Р.С., аспирант (ХНУ им. В.Н.Каразина)
}

В работе проанализированы тенденции современного этапа развития международного фондового рынка в информационной экономики. Существенное место авторами отводится позищионированию международного фондового рынка в глобальной финансовой архитектуре и той роли, которую играют трансграничные потоки капиталов в формировании ключевой тенденции. Показаны прочессы трансформации институциональной структуры международного фондового рынка и значения международных финансовых иеетров в эпоху глобализации.Определені дальнейшие чаги развития фондового рынка Украины для интеграчии в мировое хазяйство.

Ключевые слова : глобализация, международный фондовый рынок, международные финансовые центры, интернационализация, информационные технологии, ценные бумаги. 


\section{ANALYSIS OF MODERN TRENDS IN THE INTERNATIONAL STOCK MARKET}

\section{Savin R.S., postgraduate student (KNU named V.N.Karazin)}

This paper analyzes the trends the present stage of development of the international stock market. Significant the authors is given to positioning international securities market in to global contemporary architecture and the role today played by cross-border flows of capital in the formation of its key trends. Analyzes the processes of trans-formation of institutional structure of the international stock market, the stock exchange and OTC sectors, role of international financial centers, the evolution of the main financial instruments in the international stock market. Defines the role and importance of modern information technologies and innovation in the functioning of the international stock market in the era of globalization on of world economic system.

Keywords: globalization, international stock market, international financial centres, internationalization, information technology, securities.

Постановка проблема.

Ті глибокі зміни, які відбуваються останні десятиліття, зумовили швидке зростання кількісних показників, формування нових якісних сторін розвитку міжнародного фондового ринку та стали однією 3 найбільш визначних тенденцій епохи глобалізації.

Випереджуюче зростання фондового ринку в світовій економіці та пов'язаних 3 ним сегментів фінансового ринку зберігається до останнього часу внаслідок постійного зростання попиту на фінансові ресурси, а також активізації професійних учасників ринку, розширенням його традиційних та нових сегментів. Еволюція глобальних потоків капіталу, яка супроводжується циклічними коливаннями, визначає довгострокові тенденції в інституціональній структурі фондового ринку.

Аналіз сучасних тенденцій міжнародного фондового ринку $\epsilon$ вельми важливим для подальшого розвитку фондового ринку України, особливо 3 огляду на євроінтеграційні процеси, які відбуваються сьогодні в країні.

публікацій.

.Аналіз останніх досліджень i

Дослідженню фондових ринків приділяється достатньо уваги в наукових та практичних колах. В останні роки ця тема стала вельми актуальною у зв'язку з гостротою проблеми забезпечення фінансової стабільності. В межах даної статті не можливо перелічити усіх вчених та дослідників, які займаються проблемою фондових ринків. Найбільш відомі 3 них, які ведуть активну наукову полеміку це - А.П. Голіков,
О.А.Довгань [1], Котова М.В. [2], Калина А.В., Корнєєв В.В., Кощеєв А.А. [3], Корнієнко Е.Б. [4], Макконнелл К.Р., Брю С.Л. [5] та багатьох інших. Крім того, ведуться комплексні, глибокі розробки під егідою таких всесвітньо відомих фінансових організацій , як Міжнародний валютний фонд (МВФ), Світовий банк та інш.

Виділення невирішених частин загальної проблеми.

Велику актуальність сьогодні мають теоретико-методологічні питання, які вивчають сучасні тенденції, які спостерігаються на міжнародному фондовому ринку, особливо 3 точки зору ключових передумов формування сучасних фінансових трендів-глобалізації та науково-технічного прогресу та як слідство прагнення до консолідації та появи нових фінансових продуктів та засобів їх доставки. Мало уваги приділяється питанням залучення досвіду функціонування фондових ринків розвинутих країн для вдосконалення українського фондового ринку на шляху до євро інтеграції.

Метою статті $\epsilon$ аналіз сучасних тенденцій розвитку міжнародного фондового ринку в новій інформаційній економіці та їх вплив на подальше удосконалення фондового ринку України.

дослідження.

основного матеріалу

Останні два десятиліття розвитку економіки відзначені розширенням фінансових ринків в розвинутих країнах та в країнах, що розвиваються. Найбільш динамічним сегментом фінансового ринку $є$ фондовий ринок. Які ж сьогодні виділяються тенденції його розвитку та який вплив це має на розвиток 
економічних процесів, що відбуваються в світі. Однією 3 головних тенденцій сучасного міжнародного фондового ринку $\epsilon$ закономірність даного етапу економічного розвитку, а саме-глобалізація фондових ринків. Інтернаціоналізація господарського життя, яка відбувається в наступний час веде до створення всесвітнього господарства, а в фінансовій сфері - глобального фінансового ринку [5].

Глобалізація фінансових ринків призводить до вільного руху капіталів. В сучасних умовах більша їх частина пов'язана саме 3 фондовим ринком. Міжнародна статистика, у тому числі i статистика Міжнародного валютного фонду виділяє три групи інвестицій, які включають до балансу руху капіталу: прямі інвестиції, портфельні інвестиції та інш [5-6].

Відповідно до рекомендацій ОЕСР та МВФ, підприємство прямого іноземного інвестування визначається як компанія, в якій іноземний інвестор має $10 \%$ та більше голосуючих акцій або капіталу. Прямий інвестор в змозі впливати або приймати участь в управлінні підприємством [6-7].

Придбання контрольного пакету акцій зарубіжного підприємства входить в категорію прямих інвестицій. Прямі інвестиції пов'язані 3 фондовим ринком лише в частині придбання контрольних пакетів акцій іноземних компаній.

Портфельні інвестиції включають придбання часткових цінних паперів, яке не призводе до встановлення контролю над підприємством, боргових цінних паперівоблігацій, інструментів грошового ринку та деривативів. Таким чином, портфельні інвестиції повністю пов'язані 3 фондовим ринком.

Інші інвестиції - це торговельні кредити, лізинг, придбання валюти та розміщення засобів на депозитах.

Так, при розгляданні генезису інвестицій у 1970-2000 роках, можна відзначити, що обсяг прямих інвестицій із сімки ведучих економічно розвинутих країн виріс приблизно в 50 разів, а портфельних - в 150 разів [7-8]. Починаючи 3 80-х років двадцятого століття вивіз капіталу у формі портфельних інвестицій перевищував прямі інвестиції, хоча 3 кінця 90-х років співвідношення між прямими та портфельними інвестиціями почало знову змінювались у бік перших.
Глобалізація фондових ринків проявляється також у тому, що одними і тими же інструментами усе ширше торгують на різних ринках. Так, широке розповсюдження отримав лістинг акцій на декількох біржах. Це має означати, що акції найбільших елементів можуть продаватись одночасно в Нью-Йорку, Лондоні, Франкфурті, Токіо і т.д. [8]. Поширення Internet дозволило вести торгівлю акціями іноземних елементів цілого ряду країн будь-якому інвестору майже зі скромними фінансовими ресурсами, перебуваючи у монітора свого комп'ютера.

Одним 3 проявів процесу інтернаціоналізації стало злиття різних національних інститутів фондового ринку створення торгових систем та депозитарно клірингових організацій. Особливо активно цей процес відбувався в Західній Європі, чи фондовий ринок $\epsilon$ роздробленим та найменш ефективним ніж, скажімо, американський фондовий ринок.

На загальноєвропейському рівні ще 3 кінця 80-х років були спроби створення єдиної системи, яка б пов'язала усі біржі воєдино (проект PIPE, Euroquote), але цей проект не відбувся. Усі спроби створити загальноєвропейський фондовий ринок, нажаль, не мали успіху. Але ж у 1998 році виникло об'єднання низки ф'ючерських ринків європейських країн під назвою Euro-GLOBEX. Спочатку до нього увійшли два французьких та іспанська термінові біржі: MATIF, MONEP та MEFF, а в кінці 1998 року до них приєдналась італійська термінова біржа MIF. Це поклало початок створенню єдиних європейських регіональних систем.

Процес інтернаціоналізації фондових ринків має резерви подальшого поглиблення. Сучасна теорія управління портфелем (portfolio theory) говорить, що оптимально диверсифікайний портфель повинен складатися таким чином, щоб частка паперів однієї країни відповідала частці цій країни в сукупних активах. Частка іноземних активів в портфелях інституціональних інвесторів розвинутих країн наприкінці 90-х років складала тільки $20 \%$.

Інтернаціоналізація фондових, як і усіх фінансових ринків - об'єктивний процес і в цілому має позитивні наслідки для розвитку світової економіки.

Розвиток міжнародного фондового ринку є результатом складних процесів в сфері 
руху транснаціональних капіталів, які визначають їх функціональну та регіональну структуру.

В перше десятиріччя двадцять першого століття мережа транскордонних інвестицій зазнає істотні зміни, по мірі того, як відбувається розширення та поглиблення економічних та політичних зв'язків між різними регіонами та групами країн. Зростання іноземних активів визначається не тільки рухом інвестицій між великими фінансовими центрами економічно розвинутих країн, але й відображає посилення значущості фондових ринків країн, які розвиваються. Доволі ускладнюється сама система транскордонних зв'язків, а саме зростають взаємні потоки капіталів в Європі після створення євро зони, збільшуються обсяги фінансових ресурсів, які переміщуються між розвинутими країнами та країнами, які розвиваються, особливо між західноєвропейськими країнами та країнами Ближнього та Середнього Сходу, ПівденноСхідної Азії та інш. Одночасно відбувається зниження ролі США як лідируючого експортера капіталу. Так, за перше десятиліття двадцять першого століття частка США в загальному обсязі транскордонних інвестицій знизилась $350 \%$ до $32 \%$ [8-9]. В той же час розширюються потоки між регіонами, які розвиваються («південь-південь»), по мірі того, як уряди та корпорації в цих країнах стають активними гравцями на глобальних ринках. Взаємозв'язок фінансового та фондового ринків, взаємопроникнення різних інвестиційних функцій чітко просліджується в діяльності міжнародних фінансових центрів (МФЦ). Становлення МФЦ відбувалось навколо біржової інфраструктури. Саме в силу своєї широкої функціональності міжнародні фінансові центри змогли забезпечити надійні умови для залучення іноземних інвесторів. В двадцять першому столітті вони стають однією 3 основ сучасної мережевої структури світової економіки, яка забезпечує рух фінансових потоків між великими кластерами світового господарства.

На сучасному етапі розвитку міжнародного фондового ринку конкуренція між міжнародними фінансовими центрами загострюється. Інтернаціоналізація висуває більш високий рівень потреб до кількісних та якісних параметрів розвитку національних фондових ринків, що забезпечує їх глобальну конкурентоспроможність.

Конкуренція розгортається по всім основним складовим фондового ринку - інфраструктурним інститутам, фінансовим інструментам та їх інноваціям регуляторним та податковим системам. Істотно змінюються умови діяльності основних учасників даного ринку емітентів, інвесторів, професійних посередників, а також національних регуляторів фондових ринків. Особливо підвищується роль глобальних інвесторів, які забезпечують ліквідність міжнародних фондових ринків.

Підтримці конкурентних позицій МФЦ сприяла реалізація ними кластерної політики за рахунок ефективної взаємодії складових частин кластеру, який заснований на мережевій структурі споріднених та підтримуючих галузей, що забезпечує доступ до широкого кола фінансових послуг, висококваліфікованих кадрів, а також зниження трансакційних витрат внаслідок розвитку інфраструктури ринку. Особливо створення та використання розширеного кластеру фінансових послуг та пов'язаних 3 ними торгових та високотехнологічних галузей виявилося вельми стійким до розвитку. Сильні позиції на міжнародному фондовому ринку підтримуються обслуговуючими галузями, такими як консалтингові та юридичні послуги, спеціалізовані 3МІ та телекомунікації.

В умовах загострення конкурентної боротьби одним із шляхів посилення міжнародних фінансових центрів стало впровадження фінансових інновацій, а також введення в інфраструктуру центрів спеціалізованих інститутів для розробки та впровадження інноваційних продуктів.

Сьогодні фондовий ринок України усе ще перебуває на стадії становлення. Існує низка проблем, які вимагають вирішення для формування високоліквідного та достатньо капіталізованого фондового ринку.

Особливості фондового ринку України зумовлені тим, що він виник і розвивається в умовах переходу від планової економіки до змішаної економіки ринкової орієнтації. Ці умови характеризуються революційним характером перетворень, нестійкістю стану економіки і суспільства, різноманіттям можливих шляхів переходу, наявністю особливих економічних форм, що функціонують 3 використанням принципів як 
планового, так i ринкового способів господарювання. Нагальні проблеми, що існують на фондовому ринку України i заважають його подальшому розвитку - це низька ліквідність та капіталізація, масштабний дефіцит внутрішніх грошових ресурсів для інвестицій, низька частка біржового сегменту ринку, недостатнє законодавче регулювання ціноутворення, обмежена кількість ліквідних та інвестиційно привабливих фінансових інструментів, висока фрагментарність біржової та депозитарної структури [9].

Ці проблеми внутрішнього характеру мають бути усунені, бо інакше український фондовий ринок не зможе повноцінно інтегруватись в міжнародний фондовий ринок.

\section{Висновки.}

Глобалізація світової економіки сьогодні розповсюдилась на широку сферу міжнародних операцій і сприяла формуванню міжнародного фондового ринку в його сучасному вигляді. Прямий вплив на розміри та глибину міжнародного фондового ринку чинили процеси фінансової інтеграції, які призвели до усунення бар'єрів між національними та міжнародним фондовим ринком, зростання обсягів транскордонних потоків капіталу, формування нової структури учасників. Склався якісно новий рівень глобальної фінансової системи, який заснований на розширенні мережі організацій та компаній, які надають транснаціональні фінансові послуги та використовують спеціалізовані інформаційні технології.

Розвиток міжнародного фондового ринку в епоху глобалізації забезпечує необхідні умови для більш тісної взаємодії усіх сторін діяльності в сфері світових фінансів.

Для вирішення проблемних питань $\mathrm{i}$ стимулювання подальшого розвитку українського фондового ринку необхідно вирішити наступні завдання: збільшення капіталізації, ліквідності та прозорості фондового ринку; удосконалення ринкової інфраструктури та забезпечення іï надійного і ефективного функціонування; удосконалення механізмів державного регулювання, нагляду на фондовому ринку та захисту прав інвесторів; стимулювання подальшого розвитку фондового ринку України. Рішення вищезазначених питань дасть можливість наблизити національний ринок до фондових ринків розвинутих країн, що забезпечить можливість подальшої інтеграції України у світове господарство.

\section{СПИСОК ЛІТЕРАТУРИ}

1. Міжнародні економічні відносини: підручник /під ред. А.П.Голікова, О.А.Довгань.-Х.;ХНУ імені В.Н. Каразіна,2015. - 464 с.

2. Котова М.В. Трансформація фондового ринку України в умовах світової глобалізації [Електронний ресурс] /M.В. Котова, В.С.Задорожнюк//Економіка: реалії часу. Науковий журнал. - 2013. - № 1(6). C.153-157. Режим доступу:http://economics. opu.ua/files/archive/2013/n1/html/.

3. Калина А.В., Корнєєв В.В., Кощеєв А.А. Ринок цінних паперів (теорія і практика): Навч. посіб. - Київ, 2005. - 256с.

4. Корнієнко Е.Б. Фондовий ринок України: Навчальний посібник - Сімферополь, 2005. - 67c.

5. Макконнелл К. Р., Брю С.Л. Економікс: принципи, проблеми і політика.: Пер. 3 англ. 11-го вид. К.: Хагар, 2006, -785 c.

6. Benchmark Definition of Foreign Direct Investment , Third Edition.-Paris: OECD.-1996P.8

7. International Capital Markets: Developments, Prospects Key Policy Issues. IMF, Washington D. C.-2001.

8. Patel S., Sarkar A. Stock Market Crises in Developed and Emerging Markets. Federal Reserve Bank of New York.-1998-April.-P.8

9. Mapping global capital markets. Global McKinney Institute, August, 2011p. C. 32-33.

Рецензент д.е.н., професор УкрДУЗТ Зайцева І.Ю. Експерт редакційної колегії к.е.н., доцент УкрДУЗТ Уткіна Ю.М. 